\title{
Value Addition by IFRS
}

\section{Kumar VDS ${ }^{1}$ and Malyadri $\mathrm{P}^{2 *}$}

${ }^{1}$ IGNOU, Study Center-ABS, Punjagutta, Hyderabad, India

${ }^{2}$ Government Degree College, Osmania University Patancheru, Hyderabad-502 319 Telangana State, India

\begin{abstract}
In the context of India's aspirations and its corporates rightful global business aspirations in tune with its big population size and the need for greater trade, credit and investment avenues, there is an imperative need to go in for global standards in many business respects. In this respect, the need for clear corporate financial portrayals or reporting needs no overemphasis. This paper is a modest attempt at examining the corporate reporting imperatives and the Indian and International Financial Reporting Standards routes to reach them. The IFRSs are found to have value addition to corporate image and credit and investment avenues and reporting practices.
\end{abstract}

Keywords: Financial corporate image; Globalization; Divergence and convergence; Value addition

\section{Introduction}

The IFRSs have been in the accounting field for quite some time, for more than four decades (1973), quietly spreading their wings across the globe, quite naturally following the gradual march of financial liberalization and its globalization. Still there are said to be important lands of non-acceptance of following the 'universal' IFRSs, if not their outright rejection of which the USA, the economic superpower and India an emerging major (superpower) market economy appear to stand out as both of them have their own Accounting Standards [1]. There is no doubt about the Indian accounting standards being quite high and the accounting profession being strong, emerging after a tough training and exacting examination, with the government of India also bestowing its best attention upon the accounting standards and profession, by, among other things, the Accounting Standards Board (ASB) in 1977, just after 4 years of founding of the International Accounting Standards Committee (IASC) in 1973, of which India too is a member, and India as a major nation does not shirk from its international responsibilities.

Thus, it is well significant and highly welcome that Accountancy, from being a Board Room or (big) corporate concern is, today, in the public domain. It is, internationally, democratizing and socializing the highly professional profession of Accountancy [2].

Therefore, if the IFRSs can help enhance the corporate image and improve its practices, accounting and non-accounting, and make the corporates to reach out to the commonalty, as envisage by Prof. Prahalad in his famous Pyramid Theory of business it is well and good. It's public value addition to the corporates [3]. That is, the interests of the corporates, according to the management doyen Prof. Prahalad, should extend to the bottom, middle and upper socio-economic groups, especially to the last, why not corporate Accounting too?

Accordingly, this note is a modest attempt at a short or preliminary examination of corporate value addition by the IFRSs.

In what follows, first a view is taken of the need for a popular financial public reporting system, followed by an examination of the divergence and convergence of IASs and IFRSs and how following IFRSs can help value addition to the corporate image and global standing and acceptance. Still, in the light of the global financial crisis of 2008, IFRSs cannot be taken to be the final and last word in accounting standards. For, it is ethical considerations in accounting and corporate governance that put the corporate on a right functional and accountancy path [4].

There is, in other words, a need for what may be called ethical standards of corporate finances and financial accounting for, Mahatma Gandhi, who had extensive business relation in both South Africa and India, Honesty is Best Business Policy and big business holdings or corporations are akin to public trusts [5]. Even otherwise a gentle wave of ethics is well-Known to be sweeping the corporate world, from leadership to products and marketing practices, with the need for accounting practices too to fall in line. For the Mahatma, the corporate world was to be close to the common man of India, whose life is the foundation of the national economy and national wealth and management savants like the late Stephen Covey had considered Mahatma Gandhi a good business leadership role model [6].

The accounting profession, especially in India, should see to it that every rupee of corporate money is most productively spent, which is the winning biz and accounting sutra.

\section{Financial portrayal}

Finance is the life-blood of business from investment to working to marketing and it is raised by various methods and from various sources. Finance being scarce and obtained at a price needs to be utmost productive and give due returns. In India there is quarterly corporate financial reporting which impact not only the individual share prices but also BSE share indices and the investors, FIIs, NIIs, HNIs and small time or retail investors are on the lookout for good financial companies for investment [7]. There are many corporate financials to be well taken care of and well estimated and reported both for self and public consumption, with the national and international financial standards taking care of these in their own ways. There are age-old continuous efforts at establishing true standards and their up gradation from timeto-time, which is good for all concerned companies, shareholders,

*Corresponding author: Malyadri P, Principal of Government Degree College, Osmania University Patancheru, Hyderabad-502 319, Telangana State, India, Tel: 040-2768 2363; E-mail: drpm16@gmail.com

Received April 20, 2015; Accepted August 18, 2015; Published August 28, 2015

Citation: Kumar VDS, Malyadri P (2015) Value Addition by IFRS. Int J Account Res 3: 115. doi:10.4172/2472-114X.1000115

Copyright: (c) 2015 Kumar VDS, et al. This is an open-access article distributed under the terms of the Creative Commons Attribution License, which permits unrestricted use, distribution, and reproduction in any medium, provided the original author and source are credited. 
investors, regulatory authorities, governments, financial bodies, employees, HR agencies, job-hunters and agencies, international bodies, NGOs and Companies like Tata's with sound management, public values, sound financials and their true reportage are national icons and are in league of best companies in the world of Fortune 500 and Forbes and others, on the basis of their sound financial standards. They have not only traversed the $19^{\text {th }}$ and $20^{\text {th }}$ centuries but also are looking forward as a global major company to the $22^{\text {nd }}$ century, according to Ratan Tata , Chairman Tata Group, acclaimed as an outstanding business leader of our times by no less than the Cambridge university of England. Sound financials make great companies, like Apple, worth about $\$ 700$ bn.

It seems the financial world can be never free from frauds and deception and Ponzi funds and falsification of accounts and their public presentation [8]. The global financial crisis of 2008, resulting in a Great Recession akin to the devastating Great Depression of 1929-34. well-known to be due to the strange and so- called innovative financial practices of sub-prime housing loans against housing mortgages and securitization and OCT sale of these securities to the unsuspecting third party general public across the globe with the US big or too big banks to fail rating agencies and accounting firms in this new financial play [9].

Thus, IFRSs notwithstanding, the financial sector, both corporate and non-corporate is becoming increasingly prone to financial malpractices and financial misreporting and blowing-up. There are any number of shell companies from tax havens investing huge amounts in companies unaccounted money with the blown up share prices.

By its very nature the financial sector is amenable to fraud, manipulation for easy money making tax avoidance, against which IFRSs with all their high standards are no guarantee against, which however is no reason to/for their rejection and non-adoption [10]. They call for serious consideration and possible acceptance and adoption. India is envisaged a bright business future and increasing international business operations. Many bright young men and women, hardly in their 20s and from diverse disciplines are taking to start-ups and making a good success of them with international acceptance and purchase offers at good valuation. It is the global reach and heights which are the aspirations of India in every field, [11] say from education to enterprises and excellence is the watch word in Biz-arena.

\section{India's global run}

India's global run had begun in the 1990s, exactly in 1991, from quite unexpected quarters and personalities, the INC and its then accidental PM and FM, Late Sri PV Narsimha Rao and Dr. Manmohansingh, a Cambridge economic scholar of eminence, the fruits of these globalrun are quite sweet, among other things, the forex reserves have soared from almost nothing $\$ 0.5$ billion to $\$ 320$ billion and exports (Xs) to some $2 \%$ of the global X-trade from $1 \%$, notwithstanding of which $\mathrm{M}-\mathrm{X}$ imbalance continues to dog the Indian economy, from which the diving of oil prices from > USD 100/barrel to about $\$ 50$ there is some respite, in spite of being a nation of a long trading tradition dating to the Roman empire, which glory the nation has to recapture by adopting and leading in global standards, including IFRSs. Markedly, IFRS are not only voluntary and almost free products, but are also corporate finance friendly, adding to and enhancing the financial image and standing of the corporations and are well revealing than hiding.

\section{Indian and international IFRSs}

In the post liberalization period the convergence of Indian GAAP with IFRS has been much sought. In India, it is necessary to adopt the provisions of IFRS (Especially in the areas where the IAS differ with corresponding IFRS) to develop consistency with regulatory and economic environment. As IFRS is fair value driven it can be proved panacea for corporate governance issues in India [12].

- Both originate in the 1970 s of oil shocks with the need to tighten company financials.

- The intention of the two is to standardize and upgrade corporate reporting standards.

- $\quad$ Both extend to 1, 2 and 3 level enterprises, i.e. Large, medium and small enterprises.

- The two standards are arrived after strenuous efforts and allparty consultation and opinions.

- Indian as well as international standards cover the whole field of financial reporting.

- Both are consensual, based on broad agreement.

- Both are based on the fundamental principles of business and finances and their valuation.

- There is a good deal of compatibility between the two.

So, does it mean that it doesn't matter whether we have Indian or International standards? No. IFRS appear to score more in number, simplicity, objectives, sectors, applications, etc.

\section{IFRS's score}

1. They have laudable objectives, according to the IASC, the objectives are "to formulate and publish in the public interest standards to be observed in presentation of audited financial statements and to promote world-wide acceptance and observance" the democratized element "public interest" appears to be absent and moreover Indian financial standards, which alone make a lot of difference between the two and make the international standards score over the Indian ones [13].

2. Another thing in which IFRSs score over the IASs is 'simplicity' the quite difficult item of inventories is quite illustrative.

India: valuation of inventories means applicability, measurement, determine costs and reporting.

International: The treatment of inventories includes the recognition of inventory cost, explanation of net-realizable value.

3. Coverage: 32 and $42,42>32$.

4. Sectors: India-production and service.

International-production, service and agriculture.

Thus, IFRSs, without any belittling the Indian Standards, appear to be more inclusive/comprehensive and quite forward looking and quite in tune with the trends of financial globalization. In propertyland, plant and equipment, the Indian standard is 'Historical' Costs whereas the international standard is present or contemporary value, simple to assess. Even the Indian Standard involves adjustment to the inflationary factor.

There is, of course, no need for wholesale giving up of Indian Standards, which after all are very meticulously arrived at by the highly professional members of accountancy in the country, who are second 
to none in their profession in the world. What is required is the fusion or infusion of the spirit of globalization into the profession and their accounting standards. The international standards appear to have a definite edge over their Indian counter parts. Far more is their wide acceptance in many parts of the upcoming business world of China, Middle-East and others, given to more self-Image.

Overall, there appears to be a definite value addition by the IFRSs [14]. Individual corporates interested in this may go in for opt for IFRSs, following the adage, say, be a Roman while in Rome.

\section{Value addition}

Sooner or later, India and its corporations aspiring to be global players have to fall in line with the global corporate governance, business, accounting practices, etc., India's and its corporates biz destiny appears to be in globalization, green way, to overcome poverty, human underdevelopment, lethargy, apparent inefficiencies, over costs, etc., there are wide spread global complaints of India falling behind in many global biz standards, in the present case, overall, there seems a value addition to the corporates in vital respects.

- Better International corporate image.

- Higher financial portrayal.

- Far researching to the general and investing public.

- More retail Investors.

- $\quad$ Spread of corporate investment culture.

- $\quad$ Enhanced credit standing.

- Access to greater bank and other institutional finances.

- Greater access to international financial access.

- Improved accounting credibility.

- Lower borrowing costs.

- Higher good will.

- $\quad$ Spring cleaning of corporate structure and governance.

- $\quad$ Better CRs and PRs.

The increasing scale of International trade and investments in the form of FDI, FII has given rise to a demand for uniformity in the accounting system, because the procedure and presentation of results varies from country to country.

IFRS provides more compatibility among sectors, countries and companies. Due to its universal appeal, it can both improve and initiate new relationships with investors, customers and suppliers across the globe.

IFRS also provides impetus to cross-border acquisitions, enables partnership and alliances with foreign entities. It gives better access to global capital markets and reduces the cost of capital.

The gains or value additions are both tangible and intangible. In sum, it is like opting for more public friendly accounting standards of international biz fraternity. On the whole, IFRSs appear to carry good tidings for the corporate bodies in India.

\section{Conclusion}

It is time for India and its business houses to upgrade themselves to international level in every respects including financial Portrayal. It can be expected to result in enhanced returns or value addition in terms among other things of the corporates global image and accessing economical credit and investment avenues.

\section{References}

1. AICPA (1972) American Institute of Certified Public Accopuntants, Establishing financial accounting standards: Report of the study on establishment of Accounting Principles, New York.

2. Chatov (1975) Corporate Financial Reporting. The free Press 150.

3. Dey, Dutta (2000) problems on higher accountancy (5thEdn), Bhattacharjee Brothers, Calcutta.

4. Donald W Penetrating International Markets: key Considerations for smaller firms. J of Business Management.

5. Lal J (2009) Cost Accounting (4thedn) The Mc Graw-Hill publishing company limited, New Delhi.

6. Halsey RF(2001) Using the Residual-Income Stock Price Valuation Model to Teach and Learn Ratio Analysis. Issues in Accounting Education 16: 257.

7. Harvey CR (2005) 12 Ways to Calculate the International Cost of Capital. Duke University, Durham, North Carolina, USA.

8. Pandey M (2010) A Comparative Analysis of Indian Accounting Standards and International Accounting Standard. The Indian journal of commerce 63: 103104

9. Miller KD (1992) A framework for integrated risk management in International business. Journal of International Business Studies 23: 311-331

10. Shah P (2013) Financial Accounting for Management. Oxford University Press.

11. Rajasekaran, Gupta P (2011) Financial Accounting. Pearson.

12. Deb R (2014) Improving Government Accounting Practices. The Indian Journal of commerce 67: 74-75.

13. Rathore SL (2010) GAAP and IFRS: Feasibility of Convergence. The Indian Journal of Commerce 63: 49-50.

14. Rao S (2014) The Corporate Reporting Practices: An Analysis. Abhinav publication 3: 1-2. 